Vol. 13 (2004): 229-246.

\title{
On diversity effects of alternative agricultural policy reforms in Finland: an agricultural sector modelling approach
}

\author{
Antti Miettinen \\ MTT Agrifood Research Finland, Economic Research, Luutnantintie 13, FI-00410 Helsinki, Finland, \\ e-mail: antti.miettinen@mtt.fi \\ Heikki Lehtonen \\ MTT Agrifood Research Finland, Economic Research, Luutnantintie 13, FI-00410 Helsinki, Finland \\ Reija Hietala-Koivu \\ Department of Applied Biology, PO Box 27, FI-00014 University of Helsinki, Finland
}

\begin{abstract}
The European Union has decided to reform its agricultural policy and decouple Common Agricultural Policy support partially from production. The aim of this study is to predict the diversity effects of agricultural policy reforms in which direct aid payments are disconnected from production, and compare the outcomes with the effects of a policy in which Common Agricultural Policy support is coupled to production. The study employs a dynamic regional sector model of Finnish agriculture. The sector model predicts regional agricultural land use, numbers of livestock, stocking densities, pesticide application areas, and nutrient balances. Diversity of agricultural land use is measured by Shannon's diversity index. The results indicate that if agricultural support is independent from production, the amount of fallow land will increase considerably in the future. This will decrease the diversity of agricultural land use at landscape level, but may not be harmful at species level since green fallow has some positive effects, especially on the densities and abundance of farmland birds. Instead, the decrease in bovine animals is likely to run down biological diversity, since it simplifies crop rotation and diminishes grazing.
\end{abstract}

Key words: agricultural policy reform, agricultural sector model, biodiversity, landscape diversity, land use, nutrient balances, pesticides, production intensity 


\section{Miettinen, A. et al. On diversity effects of agricultural policy reforms}

\section{Introduction}

Diversity within an ecosystem enables it to survive and be productive. Species diversity, in terms of both natural plants and crop species and their varieties, may also provide a buffering effect against losses to diseases and pests or adverse weather conditions (Olson and Francis 1995, Collins and Hawtin 1999). Therefore, diversity at agroecosystem level contributes to greater food security and employment opportunities, and a risk-averse farmer may prefer to cultivate various crops in order to reach a higher expected profit.

The European Union (EU) Council of Agricultural Ministers reached an agreement on the fundamental reform of the Common Agricultural Policy (CAP) in June 2003. The key element of the reformed CAP will be a single farm payment, the size of which will become independent from agricultural production (Council of the European Union 2003). In Finland as well as in the other EU countries, agricultural support plays a significant role in the composition of farmers' income. The agricultural support in Finland consists of CAP support, compensatory allowances paid for less-favoured areas (LFA support), agrienvironmental support and national aids. The approved reform will apply only to CAP payments for arable crops and livestock. In 2003, those payments totalled $€ 447$ million and made up $26 \%$ of agricultural income subsidies in Finland (MTT Agrifood Research Finland, Economic Research and Pellervo Economic Research Institute 2004).

The environmental and social effects of agricultural policy reforms are important public concerns. The environmental effects of policies may be identified with the help of the pressurestate-response framework (OECD 2001). Agricultural policy measures (i.e. pressures) influence the state of the environment via farmers' input use and production decisions. Different agricultural production lines compete for the limited agricultural land. Hence, land use reflects relative profitability of different products and crops. The diversity of agricultural land use is a particularly important ecological and economic indicator, because land-use patterns capture and combine the effects of several simultaneous policy measures and provide information concerning economic, social and biological dimensions of diversity (Olson and Francis 1995, OECD 2001). Therefore, a change in the indicators measuring the state of the environment may trigger responses. Altogether, the evaluation of land use, diversity and other environmental indicators may provide relevant information for policymakers who consider various effects when formulating new policies.

The two policy reforms studied here and compared with the baseline scenario are the on-going reform of the CAP and the liberalised agricultural trade which is a radical trade liberalisation scenario. Extended Agenda 2000 represents the baseline scenario. These reforms differ in terms of policy parameters, i.e., support for farmers and institutional prices of agricultural products. In addition, in the on-going CAP reform and trade liberalisation scenarios, agricultural support is decoupled (i.e. direct aid payments are disconnected) from production. The effects of farm policy reforms on Finnish agricultural sector are predicted and evaluated using a dynamic regional sector model of Finnish agriculture (Lehtonen 2001, 2004). This particular model has been used in this study because it is detailed in terms of agricultural products and policy description. The sector model simulates agricultural production along with land and input use resulting from a given policy alternative. The dynamic sector model can also deal with several simultaneous or sequential changes in policy instruments.

The recent applications of agricultural sector models include Topp and Mitchell (2003) who forecasted the environmental and socio-economic effects of the Agenda 2000 proposal on the Dumfries and Galloway region in Scotland. Their environmental sub-model estimated that approximately $2.6 \%$ of the land area would change its vegetation type, and the authors concluded that diversity in landscape would be reduced by the 
Vol. 13 (2004): 229-246.

Agenda 2000. Cooper et al. (2003), in turn, analysed trade liberalisation impacts on US agriculture and reported only marginal aggregate changes. There were, however, regional variations, which indicate specialisation of production in the most feasible and competitive regions. The literature also includes impact analyses of the midterm review proposals of the Common Agricultural Policy (European Commission 2003a, b). However, these analyses, which evaluated impacts on agricultural production, income and land use at EU level, did not explicitly consider diversity effects.

In addition to diversity in agricultural land use, we also discuss the potential biodiversity effects of policy scenarios. According to Duelli (1997), biodiversity evaluation at regional level can be based on landscape parameters. Even though landscape diversity indicators give an overview of biological diversity, there are no general models which relate overall species diversity to landscape diversity (Jeanneret et al. 2003). Thus, the relationship depends strongly on the organism examined. Furthermore, according to Southwood and Way (1970), cited in Altieri (1999), the degree of biodiversity in agroecosystems depends on four main characteristics:

1. The diversity of vegetation within and around the agroecosystem

2. The permanence of the various crops within the agroecosystem

3. The intensity of management

4. The extent of the isolation of the agroecosystem from natural vegetation.

In this study, we predict policy-driven changes in the diversity of areas under arable crops, set-aside and uncultivated agricultural land, and consider the effects of agricultural land use on the diversity of some natural species. Furthermore, we discuss the permanence of vegetation as a result of different land use forms and evaluate the intensity of management resulting from a given policy alternative.

The policy scenarios and the main elements of the modelling strategy are introduced in the second section of this paper. The third section presents agricultural land use predictions and the corresponding values of Shannon's diversity index. In addition to diversity index values, environmental indicators quantifying intensity of agricultural production, i.e., stocking densities, aggregate nutrient balances and pesticide application areas, are used to improve the analysis of potential policy effects on the state of the environment and biodiversity. It is especially interesting to see the environmental performance of the CAP reform scenario, because the EU Commission has announced that the on-going CAP reform will promote the environment. Finally, implications on biological diversity are discussed and conclusions are drawn in the last section of the study.

\section{Methods}

\section{Dynamic regional sector model of Finnish agriculture}

Our study employed the dynamic regional sector model of Finnish agriculture (DREMFIA), which, when given the reform-specific policy parameters, simulated the Finnish agricultural sector till year 2020. The main elements of the DREMFIA model are briefly presented in the Appendix, and a thorough description of the model is found in Lehtonen (2001). The sector model assumes that farmers maximise their profits when there are fixed resources (land) and competitive markets. Hence, the relative profitability between different products, affected by agricultural and environmental policy measures, determine the long-term changes in land use. The outcomes of the sector model include hectares planted to 13 different crops, areas of bare and green set-asides, and the amount of marginal land left out of agricultural production. This last category consists of areas in which land rent in agricultural use is negative. The sector model also predicts stocking densities, regional farm gate aggregates of nutrient balances and pesticide 
Miettinen, A. et al. On diversity effects of agricultural policy reforms

application areas which indicate the intensity of agricultural production.

Because agricultural support varies regionally in Finland, it is logical to examine the effects of policy reforms in differing geographical areas. The sector model includes four main regions, northern Finland, Ostrobothnia, central Finland, and southern Finland (Fig. 1). According to Uusitalo (2003), most of the crop production in Finland is located in southern and southwestern Finland and in Ostrobothnia. Dairy farming is regionally quite evenly distributed, but with a dominant line of production in central and northern Finland. Most of the piglet and pork farms are located in southern and western Finland. The location of livestock production is reflected in the regional distribution of land use; the share of grassland in the cultivated area is large outside southern Finland.

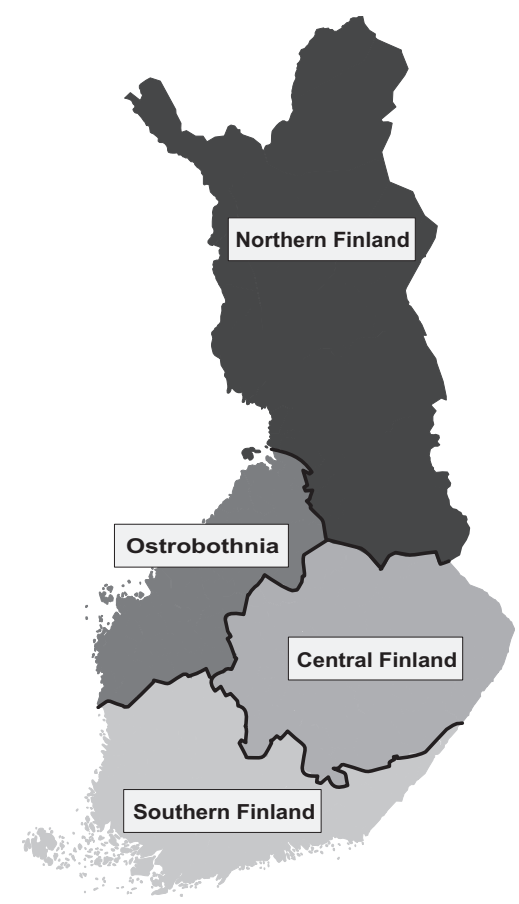

Fig. 1. Main regions in the dynamic regional sector model of Finnish agriculture (DREMFIA).

\section{Policy scenarios}

The base scenario (i.e. extended Agenda 2000) provided the baseline forecast for the development path of agriculture in Finland. The predictions of alternative policy scenarios, the on-going CAP reform and the liberalised agricultural trade, were compared with the results of the base scenario. Since adjustment to a policy change takes a long time, we compared the diversity of agricultural land use and production intensity between policy scenarios based on the sector model predictions of agricultural land use and production in 2015 . The scenarios were chosen because they represent different degrees of decoupling of direct aids. In the base and on-going CAP reform scenarios, the LFA, agri-environmental and national supports were assumed to remain at 2003 levels.

\section{Agenda 2000}

On the basis of Agenda 2000 agreement, adopted at the European Council in 1999, the price support for cereals and beef was reduced in 2000 and 2001. The resulting income losses to agricultural producers were partly compensated by increasing direct support, a share of which was paid from national funds. In the Agenda 2000 CAP reform, Finland was granted a permission to pay silage maize support (paid in the other EU countries) for grass, since maize is not grown in Finland. A special supplementary compensation for the drying costs of cereals and oilseed plants (a.k.a. drying aid) was implemented exclusively in Finland and in northern Sweden. The reform of milk and milk products will be realised starting from the marketing year 2005/06. The administrative prices of butter and skimmedmilk powder will be cut by $15 \%$ in total until the marketing year 2007/08 (Ala-Mantila et al. 2000).

\section{On-going reform of the Common Agricultural Policy}

The on-going CAP reform scenario (from now on REF scenario) followed the CAP reform agreement made in June 2003, according to 
Vol. 13 (2004): 229-246.

which most direct CAP subsidies will be decoupled from production and paid in a single, lumpsum farm payment based on 2000-2002 historical production levels (Council 2003). On options given for the EU member states, the Finnish government has decided that the implementation of the reform will start in 2006. From there on, all CAP arable area payments will be decoupled from production and a regionalised flat-rate payment will be paid for all farms and all crops (including set-aside, but excluding some permanent crops). Also decoupled CAP animal support, based on 2000-2002 production, will be paid for individual farms. However, $75 \%$ of bull premia and $100 \%$ of suckler cow premium will remain coupled to production, i.e. paid per animal. The sum of coupled bull and suckler cow premia will not exceed $75 \%$ of the bull premia paid in the reference period 2000-2002. The farm-specific payments of decoupled animal support will be later included in the flat-rate payment (MMM 2004).

Receiving decoupled CAP support will not require any agricultural commodity production. However, farmland has to be kept in good agricultural and environmental condition, and this means in practice that land has to be either cultivated or kept as set-aside land. In the REF scenario, no change in the EU level cereal prices is assumed. The intervention prices of butter and skimmed-milk powder will decrease by $25 \%$ and $15 \%$, respectively, in 2004-2007. In 2007, it is assumed that the overall decrease in the average producer price of milk at the EU level will be $16 \%$ down from the 2003 price level. The price cuts will be compensated to by a direct payment of $€ 35.50$ per ton of milk quota. This payment becomes fully decoupled in 2007. Furthermore, $5 \%$ of all direct EU payments will be cut (modulated) from 2007.

\section{Liberalised agricultural trade}

In the liberalised agricultural trade scenario (later LIB scenario), it was assumed that the global trade liberalisation will lead to the following drastic adjustments and reforms in agricultural policy. From 2010 onwards all agricultural sup- port, including national, LFA and agri-environmental support, will be decoupled from production and transformed into an area-based flat-rate support. Direct area payments will thus be equal for all crops and set-aside. Receiving support includes a requirement of maintaining land in good agricultural condition. The total sum of agricultural support will be reduced by $15 \%$ by year 2014. The prices of agricultural products in the EU will fall to world market price levels which are assumed to be 5-20\% lower than the price levels in the REF scenario. EU cereal prices will decrease by $8 \%$ whereas beef and poultry meat prices will decrease by $20 \%$ and pork prices by $10 \%$ from the 2002 level until 2010 . These price cuts will not be compensated to producers. In the LIB scenario, the milk quota system was presumed to be abolished by 2010. It is assumed that the consequent reduction in butter prices will be $35 \%$ and $17.5 \%$ in skimmed-milk powder prices, resulting in a $28 \%$ reduction in the producer price of milk at EU level. Compensation paid for dairy farms would be $€ 40.10$ per ton of quota, fully decoupled after the abolition of the quotas.

\section{Diversity of agricultural land use}

The diversity of agricultural land use comprises of richness and evenness (Olson and Francis 1995). Richness of agricultural land use refers here to the number of different land-cover classes, i.e. cultivated crops as well as bare and green fallow and uncultivated marginal agricultural land (Table 1). Evenness of agricultural land use, for its part, refers to the uniformity of distribution of the area among land-cover classes.

Shannon's diversity index (SHDI) was applied in the land-cover diversity calculations (McGarigal and Marks 1995). The index is based on information theory (Shannon 1948) and it is frequently used in diversity quantifications (cf. Di Falco and Perrings 2003, Hietala-Koivu et al. 2004). The values of SHDI were calculated according to the formula: 


\section{Miettinen, A. et al. On diversity effects of agricultural policy reforms}

$$
S H D I=-\sum_{i=1}^{m}\left(P_{i} \times \ln P_{i}\right),
$$

where $m$ is the number of land-cover classes, $P_{i}$ measures the proportion of area covered by landcover type $i$ and ln denotes natural logarithm. $S H D I$ is equal to zero when the agricultural area contains only one land-cover class (i.e. no diversity). The value of Shannon's diversity index increases as the number of different land-cover classes increases and/or the proportional distribution of the area among land-cover classes becomes more equitable. Hence, for a given number of land-cover classes, SHDI reaches its maximum when the proportions of land-cover classes are uniform, i.e. $P_{1}=P_{2}=\ldots=P_{m}=1 / \mathrm{m}$ (McGarigal and Marks 1995).

\section{Stocking density, livestock number, nutrient balance and pesticide application area}

Livestock stocking densities measure the intensity of animal production. Low density typically benefits the environment. Stocking density for bovines was calculated by dividing the livestock units (LU) by hectares of area under grass. Instead, when calculating stocking densities for pigs and poultry, hectares of fodder cereals (barley, oats and mixed cereals) were used as a denominator. We also reported the total number of bovine animals because of their biodiversityenhancing link to grazing and grass feed production.

The aggregate surface balances (surplus/deficit) for nitrogen and phosphorus per cultivated area, excluding set-aside, were calculated by adding the nutrient content of fertilisers, organic manure, and nitrogen depositions, and by subtracting the mineral content of the harvest and losses to the atmosphere. The calculated nutrient surplus $\left(\mathrm{kg} \mathrm{ha}^{-1}\right)$ provides an indicator of the production intensity, and of the potential nutrient losses and environmental damage to surface and ground waters.
The amount of pesticide application area was also reported. Chemical pesticides enhance agricultural productivity but also pose potential risks to human health and the environment. They may, for example, cause contamination of surface water.

\section{Links to biological diversity}

The whole spectrum of biodiversity is complex and impossible to measure thoroughly (Duelli 1997). Therefore we focused on agricultural land use and measured its diversity at landscape level. According to Jeanneret et al. (2003), the relationship between landscape and species diversities strongly depends on the organism examined. Since agricultural land provides habitat area for both crops and wildlife (especially weeds, vascular plants, insect pollinators and birds), we based our analysis on previous studies. The effects of land use changes to wildlife species diversity were discussed by means of examples from the relevant literature. Furthermore, in many OECD countries the expansion of farm production and intensification of input use are considered a major cause of the loss of biodiversity (OECD 2001). Our approach also caters for these things even though the share of agricultural land in Finland is less than 10\% of the total area (Yearbook of farm statistics 2002).

While the Finnish agricultural sector model is applicable when predicting agricultural land use diversity, there are also some shortcomings in the approach used. Most importantly, since not designed for that purpose, the sector model ignores areas of field verges, buffer zones, traditional rural biotopes and other semi-natural habitats which are important from the point of view of biological diversity. Furthermore, to enable more accurate spatial analyses and predictions of the environmental effects of agriculture, the land use predictions of the agricultural sector model should have been disaggregated to field parcel level. 
Vol. 13 (2004): 229-246.

\section{Results}

\section{Diversity of agricultural land use}

The aggregate agricultural land use results of the base, REF and LIB scenarios for 2015 are presented in Table 1. The table shows also the initial land allocation which corresponds to year 2002 and was also calculated using the DREMFIA model.

Agricultural land use predictions for four regions (southern Finland, central Finland, Ostrobothnia, and northern Finland) are summarised in Table 2, where certain land-cover classes are pooled and some others (i.e. oilseed plants, peas, potatoes and sugar beets) are excluded to save space. The diversity of agricultural land use in each region and in whole Finland was measured by Shannon's diversity index, the values of which are reported in Table 3.

\section{Continuation of Agenda 2000}

The base run of the agricultural sector model indicated with certain exceptions that if the Agenda 2000 policy continued, there would be no substantial changes in the proportional areas of land-cover classes in the future (Table 1). However, the total amount of cultivated area, including fallow and cultivated grassland, would decrease significantly. The most important change therefore concerns the amount of marginal farmland taken out of production, the area of which would increase more than ten times from 2002 to 2015 . Such a change results mainly from investments in larger dairy facilities which, in turn, lead to a regional concentration of agricultural commodity production within each individual region studied. Consequently, the demand for feed (grain and grass) decreases in many areas. This weakens endogenous market prices and the profitability of grain production. Because also pork and poultry production con-

Table 1. Use of agricultural land in Finland as a result of policy scenarios.

\begin{tabular}{|c|c|c|c|c|c|c|c|c|}
\hline & \multicolumn{2}{|c|}{$\begin{array}{c}\text { Initial land } \\
\text { allocation in } 2002\end{array}$} & \multicolumn{2}{|c|}{$\begin{array}{l}\text { Base scenario } \\
\quad \text { in } 2015\end{array}$} & \multicolumn{2}{|c|}{$\begin{array}{l}\text { On-going CAP } \\
\text { reform in } 2015\end{array}$} & \multicolumn{2}{|c|}{$\begin{array}{l}\text { Liberalised agri- } \\
\text { cultural trade in } 2015\end{array}$} \\
\hline & 1000 ha & $\%$ & 1000 ha & $\%$ & 1000 ha & $\%$ & 1000 ha & $\%$ \\
\hline Spring wheat & 95.843 & 4.37 & 124.524 & 5.68 & 116.527 & 5.31 & 122.034 & 5.56 \\
\hline Winter wheat & 63.552 & 2.90 & 1.392 & 0.06 & 1.499 & 0.07 & 1.099 & 0.05 \\
\hline Rye & 27.329 & 1.25 & 28.200 & 1.29 & 0.069 & 0.00 & 0.070 & 0.00 \\
\hline Barley & 527.397 & 24.04 & 433.748 & 19.77 & 330.517 & 15.07 & 288.555 & 13.16 \\
\hline Oats & 430.876 & 19.64 & 526.435 & 24.00 & 454.349 & 20.71 & 508.691 & 23.19 \\
\hline Mixed grain & 14.615 & 0.67 & 22.317 & 1.02 & 20.620 & 0.94 & 13.418 & 0.61 \\
\hline Oilseed plants & 64.158 & 2.93 & 63.513 & 2.90 & 60.871 & 2.78 & 34.121 & 1.56 \\
\hline Peas & 5.817 & 0.27 & 4.127 & 0.19 & 4.108 & 0.19 & 4.016 & 0.18 \\
\hline Potatoes & 30.536 & 1.39 & 28.425 & 1.30 & 28.165 & 1.28 & 3.399 & 0.16 \\
\hline Sugar beet & 29.137 & 1.33 & 27.539 & 1.26 & 25.585 & 1.17 & 7.927 & 0.36 \\
\hline Dry hay & 79.872 & 3.64 & 58.094 & 2.65 & 31.918 & 1.46 & 30.790 & 1.40 \\
\hline Silage & 259.728 & 11.84 & 227.853 & 10.39 & 215.500 & 9.82 & 116.476 & 5.31 \\
\hline Green fodder & 325.154 & 14.82 & 302.027 & 13.77 & 259.990 & 11.85 & 213.715 & 9.74 \\
\hline Bare fallow & 52.146 & 2.38 & 0.507 & 0.02 & 5.905 & 0.27 & 15.466 & 0.71 \\
\hline Green fallow & 173.871 & 7.93 & 167.308 & 7.63 & 637.791 & 29.08 & 832.893 & 37.97 \\
\hline $\begin{array}{l}\text { Uncultivated } \\
\text { agricultural land }\end{array}$ & 13.444 & 0.61 & 177.464 & 8.09 & 0.060 & 0.00 & 0.806 & 0.04 \\
\hline Total & 2193.474 & 100.00 & 2193.474 & 100.00 & 2193.474 & 100.00 & 2193.474 & 100.00 \\
\hline
\end{tabular}


Miettinen, A. et al. On diversity effects of agricultural policy reforms

Table 2. Regional use of agricultural land as a result of policy scenarios.

\begin{tabular}{|c|c|c|c|c|c|c|c|c|}
\hline & \multicolumn{2}{|c|}{$\begin{array}{c}\text { Initial land } \\
\text { allocation in } 2002\end{array}$} & \multicolumn{2}{|c|}{$\begin{array}{l}\text { Base scenario } \\
\text { in } 2015\end{array}$} & \multicolumn{2}{|c|}{$\begin{array}{l}\text { On-going CAP } \\
\text { reform in } 2015\end{array}$} & \multicolumn{2}{|c|}{$\begin{array}{l}\text { Liberalised agri- } \\
\text { cultural trade in } 2015\end{array}$} \\
\hline & 1000 ha & $\%$ & 1000 ha & $\%$ & 1000 ha & $\%$ & 1000 ha & $\%$ \\
\hline \multicolumn{9}{|l|}{ Southern Finland } \\
\hline Cereal area ${ }^{1)}$ & 764.114 & 68.01 & 711.811 & 63.35 & 617.789 & 54.98 & 713.082 & 63.46 \\
\hline Grass area ${ }^{2)}$ & 175.651 & 15.63 & 166.148 & 14.79 & 125.948 & 11.21 & 119.209 & 10.61 \\
\hline Fallow area $a^{3)}$ & 79.634 & 7.09 & 76.042 & 6.77 & 276.436 & 24.60 & 245.496 & 21.85 \\
\hline $\begin{array}{l}\text { Uncultivated } \\
\text { agricultural land }\end{array}$ & 0.008 & 0.00 & 61.872 & 5.51 & 0.008 & 0.00 & 0.754 & 0.07 \\
\hline Total area & 1123.588 & 100.00 & 1123.588 & 100.00 & 1123.588 & 100.00 & 1123.588 & 100.00 \\
\hline \multicolumn{9}{|l|}{ Central Finland } \\
\hline${\text { Cereal } \text { area }^{1)}}^{1}$ & 130.133 & 32.99 & 124.547 & 31.57 & 73.023 & 18.51 & 84.130 & 21.33 \\
\hline Grass area ${ }^{2)}$ & 198.655 & 50.36 & 169.066 & 42.86 & 148.147 & 37.56 & 79.230 & 20.09 \\
\hline Fallow area ${ }^{3)}$ & 52.753 & 13.37 & 28.899 & 7.33 & 172.709 & 43.78 & 230.471 & 58.43 \\
\hline $\begin{array}{l}\text { Uncultivated } \\
\text { agricultural land }\end{array}$ & 10.175 & 2.58 & 71.454 & 18.11 & 0.005 & 0.00 & 0.005 & 0.00 \\
\hline Total area & 394.457 & 100.00 & 394.457 & 100.00 & 394.457 & 100.00 & 394.457 & 100.00 \\
\hline \multicolumn{9}{|l|}{ Ostrobothnia } \\
\hline Cereal area ${ }^{1)}$ & 258.328 & 44.64 & 297.524 & 51.41 & 224.602 & 38.81 & 133.215 & 23.02 \\
\hline Grass area $^{2}$ & 209.413 & 36.19 & 185.062 & 31.98 & 171.909 & 29.71 & 97.631 & 16.87 \\
\hline Fallow area ${ }^{3)}$ & 88.393 & 15.27 & 60.491 & 10.45 & 167.412 & 28.93 & 344.032 & 59.45 \\
\hline $\begin{array}{l}\text { Uncultivated } \\
\text { agricultural land }\end{array}$ & 0.047 & 0.01 & 20.244 & 3.50 & 0.047 & 0.01 & 0.047 & 0.01 \\
\hline Total area & 578.712 & 100.00 & 578.712 & 100.00 & 578.712 & 100.00 & 578.712 & 100.00 \\
\hline \multicolumn{9}{|l|}{ Northern Finland } \\
\hline Cereal area $^{1)}$ & 7.035 & 7.27 & 2.734 & 2.83 & 8.167 & 8.44 & 3.440 & 3.56 \\
\hline Grass area $^{2)}$ & 81.035 & 83.79 & 67.698 & 70.00 & 61.403 & 63.49 & 64.910 & 67.11 \\
\hline Fallow area $a^{3)}$ & 5.238 & 5.42 & 2.383 & 2.46 & 27.138 & 28.06 & 28.359 & 29.32 \\
\hline $\begin{array}{l}\text { Uncultivated } \\
\text { agricultural land }\end{array}$ & 3.214 & 3.32 & 23.894 & 24.70 & 0.000 & 0.00 & 0.000 & 0.00 \\
\hline Total area & 96.717 & 100.00 & 96.717 & 100.00 & 96.717 & 100.00 & 96.717 & 100.00 \\
\hline
\end{tabular}

${ }^{1)}$ Cereal area includes spring wheat, winter wheat, rye, barley, oats and mixed grain.

2) Grass area includes dry hay, silage and green fodder.

3) Fallow area consists of bare and green fallow.

tinue to concentrate into large production units, some agricultural land is left idle. The relative increase in the uncultivated land area will be largest in northern Finland, but the absolute changes are largest in southern and central Finland (Table 2).
Of the single crops, the area under oats increases, and the area under barley decreases along with the continuation of Agenda 2000. Table 1 also indicates that cultivation of winter wheat becomes relatively unprofitable, and the area under winter wheat decreases markedly by 
Vol. 13 (2004): 229-246.

Table 3. Values of Shannon's diversity index.

\begin{tabular}{lcccc}
\hline & $\begin{array}{c}\text { Initial land } \\
\text { allocation }\end{array}$ & Base scenario & $\begin{array}{c}\text { On-going } \\
\text { CAP reform }\end{array}$ & $\begin{array}{c}\text { Liberalised } \\
\text { agricultural trade }\end{array}$ \\
\hline Southern Finland & 2.13 & 2.15 & 1.93 & 1.79 \\
Central Finland & 1.95 & 1.80 & 1.52 & 1.40 \\
Ostrobothnia & 1.97 & 1.97 & 1.83 & 1.34 \\
Northern Finland & 1.47 & 1.33 & 1.65 & 1.50 \\
Whole Finland & 2.20 & 2.17 & 1.95 & 1.76 \\
\hline
\end{tabular}

2015. This is due to higher production costs of winter wheat compared to spring wheat, while there is little difference in the crop yields between them. Also the amount of bare fallow land diminishes in the future.

The above-mentioned changes in land allocation lead to a bit more uneven aggregate landcover class distribution in 2015. Therefore, the value of Shannon's diversity index in 2015 calculated for the whole of Finland is lower than the corresponding value in 2002 (Table 3 ). There are, however, regional differences. Under Agenda 2000, the decline in agricultural land use diversity occurs in central and northern Finland. Instead, in southern Finland, the value of SHDI will slightly increase along with the increase in the uncultivated agricultural area.

\section{Agenda 2000 vs. the on-going reform of Common Agricultural Policy}

When comparing the agricultural land use predictions of the on-going CAP reform scenario for 2015 to the corresponding results of the extended Agenda 2000 scenario, we found that the REF scenario resulted in an almost four times larger green fallow area than the base scenario (Table 1). Correspondingly the areas devoted to barley, oats and grass will be significantly smaller under the REF scenario. These differences are due to cuts in milk price and decoupled CAP payments which considerably reduce incentives to invest in milk production in the REF scenario. Since farms are small and production costs are high, most dairy farmers who exit milk production make only the minimum effort to receive the CAP payments, i.e., they leave their land as set-aside. Only the most feasible areas of earlier grasslands will be used for grain production. In relative terms, the difference in the green setaside area between the two scenarios is largest in northern and central Finland. In both regions, green set-aside area will increase significantly as a result of the REF scenario.

Table 1 also indicates that the cultivation of rye almost comes to an end as a consequence of the CAP reform proposals which include elimination of the intervention system for rye. In addition, the amount of winter wheat cultivated in 2015 is minimal as a result of both scenarios.

As a whole, the land-use predictions for the year 2015 indicate that agricultural land-use diversity, measured by SHDI, will typically be lower due to the on-going CAP policy reform when compared to the continuation of Agenda 2000. The only exception occurs in northern Finland, where the distribution of land-cover classes will become more even under the REF scenario, and the corresponding value of SHDI higher compared to the base scenario (Tables 2 and 3). This is mainly because of a decrease in silage and green fodder areas, both of which are dominating land-cover classes in northern Finland. In addition, opposite to the other regions, the ongoing CAP reform will slightly increase the cereals area of northern Finland (Table 2). Thus, when northern dairy farmers exit unprofitable dairy production, this not only adds set-aside areas, but will also lead to a small increase in grain areas on those former grasslands where the costs of feed grain cultivation can be covered. Furthermore, there will be no marginal agricultural land in northern Finland under the REF scenario. 


\section{Miettinen, A. et al. On diversity effects of agricultural policy reforms}

Agenda 2000 vs. liberalised agricultural trade Under the LIB scenario, $38 \%$ of the agricultural land area will be devoted to green set-aside in 2015 (Table 1) the area of which will be approximately five times larger than under the base scenario. The relative difference between the scenario predictions in green set-aside areas is greatest in northern and central Finland. A dramatic increase in fallow area is due to the fact that the world market prices alone do not provide a sufficient incentive to carry on animal and cereals production on most farms in Finland. Since areabased flat-rate support can be obtained if farmland is kept in good agricultural condition, which is the case in fallow land, the vegetated set-aside thus provides a low-cost alternative to bare fallow, because the vegetation does not need to be renewed every year (MKL 1995).

Under liberalised agricultural trade, the areas under fodder cereals (especially under barley), green fodder, and silage decrease markedly. Table 1 also implies that compared to the base scenario, the area under each cereal is smaller as a result of the LIB scenario. In addition, the liberalised trade of agricultural products will bring down potato and sugar beet areas in Finland.

Due to the high dominance of vegetated fallow land, the values of SHDI for the LIB scenario are clearly lower than that of the base scenario in every region except in northern Finland (Table 3). In northern Finland, trade liberalisation will especially decrease the area under silage grass, which is initially a dominant landcover class, and will thus make the distribution of land-cover classes more uniform.

\section{Stocking density, livestock number, nutrient balance and pesticide application area}

The effects of the different agricultural policies on livestock densities are shown in Table 4. At the whole country level, the policy scenarios result in almost equal livestock densities. Instead, in Ostrobothnia and southern Finland, the densities of bovine animals will increase under the REF and LIB scenarios. This somewhat unexpected result is due to the fact that the remaining dairy and beef production concentrates into these regions and into large production units. In consequence, the availability of grassland near large farms will decrease and become more costly, which will lead to more intensive production despite of reduced agricultural product prices and dairy cow volumes in the REF and LIB scenarios.

Table 5 indicates that the number of dairy cows will decrease in the future as a result of reductions in the producer price of milk and of decoupling support from production. Even in the base scenario, fixed milk quotas and increasing yields per dairy cow will lead to reductions in animal numbers. While the number of dairy cows and the aggregate beef production will decrease, the number of beef cattle will increase by 2015 in the base and REF scenarios. The increases in both scenarios arise from the assumption that Finnish consumers have a strong preference for domestic meat, which, along with short supply, will keep domestic beef prices in Finland high.

The simulated beef prices and beef cattle numbers in Table 5 are sensitive to the consumer preference assumption. The calibrated substitution elasticities, which explain higher beef prices in Finland compared to the EU prices in the ex-post period, may exaggerate future domestic beef prices and hence the beef cattle numbers in Finland. If Finnish consumers alter their consumption habits and shift to imported beef, then domestic beef prices and cattle numbers will go down in the future. Considerably lower beef prices and number of animals would also bring down phosphorous balances which tend to remain high or even increase, as in Ostrobothnia in the current analysis (Table 6). One should also notice that, in the LIB scenario, the major decrease in EU beef prices will result in decreasing beef prices in Finland, despite consumers' strong preference for domestic beef. If the preference becomes weaker, the decline of beef cattle numbers will be more rapid than the simulated values in Table 5 point out. 
Vol. 13 (2004): 229-246.

Table 4. Livestock units (LU) per grass or feed hectare.

\begin{tabular}{lcccc}
\hline & $\begin{array}{c}\text { Initial land } \\
\text { allocation }\end{array}$ & Base scenario & $\begin{array}{c}\text { On-going } \\
\text { CAP reform }\end{array}$ & $\begin{array}{c}\text { Liberalised } \\
\text { agricultural trade }\end{array}$ \\
\hline $\begin{array}{l}\text { Bovines (LU/grass hectare) })^{1)} \\
\text { Southern Finland }\end{array}$ & 1.06 & 1.02 & 1.07 & 1.07 \\
Central Finland & 0.82 & 0.84 & 0.80 & 0.93 \\
Ostrobothnia & 0.95 & 0.95 & 0.99 & 1.01 \\
Northern Finland & 0.65 & 0.61 & 0.52 & 0.26 \\
Whole Finland & 0.90 & 0.90 & 0.90 & \\
Pigs (LU/feed hectare) $)^{2)}$ & & & & 0.90 \\
Southern Finland & 0.26 & 0.24 & 0.31 & 0.21 \\
Central Finland & 0.17 & 0.11 & 0.18 & 0.44 \\
Ostrobothnia & 0.30 & 0.25 & 0.22 & 0.29 \\
Northern Finland & 0.27 & 0.37 & 0.12 & 0.25 \\
Whole Finland & 0.26 & 0.23 & 0.27 & 0.22 \\
Poultry (LU/feed hectare) & & & & \\
Southern Finland & & 0.25 & 0.29 & 0.01 \\
Central Finland & 0.23 & 0.00 & 0.01 & 0.02 \\
Ostrobothnia & 0.01 & 0.06 & 0.03 & 0.18 \\
Northern Finland & 0.07 & 0.07 & 0.02 & 0.19 \\
Whole Finland & 0.02 & 0.17 & & \\
\hline
\end{tabular}

1) Grass area includes dry hay, silage and green fodder.

${ }^{2)}$ Feed area includes barley, oats and mixed cereals.

Table 5. Number of bovine animals.

\begin{tabular}{lcccc}
\hline 1000 animals & $\begin{array}{c}\text { Initial land } \\
\text { allocation }\end{array}$ & Base scenario & $\begin{array}{c}\text { On-going } \\
\text { CAP reform }\end{array}$ & $\begin{array}{c}\text { Liberalised } \\
\text { agricultural trade }\end{array}$ \\
\hline Dairy cows & 356.1 & 290.3 & 256.8 & 167.8 \\
Suckler cows & 29.8 & 47.8 & 33.5 & 27.3 \\
Other bovine animals & 358.9 & 320.5 & 275.1 & 183.7 \\
\hline
\end{tabular}

The pig and poultry numbers are not presented in the table, but the decrease in their volume will be less radical than in the dairy sector. Liberalised agricultural trade will lead into the largest reduction in animal numbers. Instead, the differences between the effects of Agenda 2000 and the on-going CAP reform on pork and poultry production volumes will be small.

Regional differences in aggregate nutrient balances $\left(\mathrm{kg} \mathrm{ha}^{-1}\right)$ are considerable (Table 6). Both nitrogen and phosphorus surpluses are clearly largest in northern Finland already in 2002. This is due to the dominance of dairy pro- duction and the use of purchased feeds, such as concentrates and grain, in cattle feeding. In 2015, the LIB scenario will result in the lowest aggregate nitrogen and phosphorus surpluses in every region except in Ostrobothnia. This is because the liberalised trade of agricultural products concentrates animal husbandry into Ostrobothnia, which together with low-cost imported feed grain results in a slightly higher phosphorus balance than the base or REF scenarios.

Table 7 indicates that the agricultural areas treated with chemical pesticides will typically be smaller in future than today. The exceptions 
Miettinen, A. et al. On diversity effects of agricultural policy reforms

Table 6. Nutrient balances (kg/cultivated ha).

\begin{tabular}{|c|c|c|c|c|}
\hline & $\begin{array}{l}\text { Initial land } \\
\text { allocation }\end{array}$ & Base scenario & $\begin{array}{l}\text { On-going } \\
\text { CAP reform }\end{array}$ & $\begin{array}{c}\text { Liberalised } \\
\text { agricultural trade }\end{array}$ \\
\hline \multicolumn{5}{|l|}{ Nitrogen } \\
\hline Southern Finland & 40.3 & 36.6 & 35.1 & 33.8 \\
\hline Central Finland & 42.3 & 42.5 & 49.1 & 35.5 \\
\hline Ostrobothnia & 42.3 & 42.6 & 42.1 & 37.8 \\
\hline Northern Finland & 86.3 & 96.2 & 100.0 & 60.9 \\
\hline Whole Finland & 43.2 & 41.4 & 41.9 & 36.1 \\
\hline \multicolumn{5}{|l|}{ Phosphorus } \\
\hline Southern Finland & 4.9 & 5.0 & 5.3 & 3.8 \\
\hline Central Finland & 8.3 & 7.6 & 9.0 & 6.9 \\
\hline Ostrobothnia & 8.3 & 7.2 & 8.0 & 8.2 \\
\hline Northern Finland & 12.2 & 12.4 & 11.2 & 7.0 \\
\hline Whole Finland & 6.7 & 6.3 & 6.8 & 5.1 \\
\hline
\end{tabular}

occur in Ostrobothnia under the base scenario and in northern Finland under the REF scenario, where larger cereal areas will lead to larger pesticide application areas. If we examine the landuse results at the whole country level in 2015, the pesticide application areas will be largest as a result of the base scenario and smallest as a result of the LIB scenario.

When interpreting the results above, it is worth noting that the DREMFIA model does not include organic farming where no artificial fertiliser or pesticides are used. Hence only the relative differences between the scenario results are important, not the absolute nutrient surpluses or pesticide application areas.

\section{Regional review of results}

Compared to the base scenario, decoupling of CAP support from production may slightly decrease the area under cereals in southern Finland. The changes in dairy sector are clearly seen in the proportion of grassland area, which in southern Finland will be almost 25\% smaller in 2015 as a result of the REF scenario. Instead, the fallow area may be over three times larger than under Agenda 2000 in 2015. These differences in grassland and fallow areas due to decoupling are also significant in absolute terms, since over a half of the total agricultural area is located in southern Finland.

Table 7. Pesticide application area (1000 ha).

\begin{tabular}{lccrr}
\hline & $\begin{array}{c}\text { Initial land } \\
\text { allocation }\end{array}$ & Base scenario & $\begin{array}{c}\text { On-going } \\
\text { CAP reform }\end{array}$ & $\begin{array}{c}\text { Liberalised } \\
\text { agricultural trade }\end{array}$ \\
\hline Southern Finland & 865.023 & 815.590 & 717.610 & 754.221 \\
Central Finland & 132.643 & 125.033 & 73.552 & 84.706 \\
Ostrobothnia & 278.545 & 312.728 & 238.864 & 136.937 \\
Northern Finland & 7.230 & 2.742 & 8.176 & 3.449 \\
Whole Finland & 1283.441 & 1256.094 & 1038.202 & 979.314 \\
\hline
\end{tabular}


Vol. 13 (2004): 229-246.

Ostrobothnia is the second largest agricultural area included in the sector model. If direct aids are decoupled from production, the area under cereals in 2015 will be over $20 \%$ smaller than as a result of the base scenario. Fallow area, in turn, will be almost three times bigger. In grassland area, the deviation from Agenda 2000 is small, if CAP animal support is partially coupled to production. Instead, if it is fully decoupled, the changes in proportions of land-cover classes and diversity measure by SHDI might be considerable in Ostrobothnia.

When CAP support is disconnected from production, the cereals area will decrease relatively most in central Finland. In 2015, it will be approximately $30 \%$ smaller than as a result of Agenda 2000 policy. The grassland area in turn will be at least $10 \%$ smaller, but the fallow area may be over five times larger.

It is possible that the cereals area in northern Finland might increase slightly if CAP support is decoupled from production. The greatest increase is, however, in the fallow area, which, compared to the base scenario prediction in 2015 , will be over 10 times larger as a result of the REF or LIB scenario. The area under grass, for its part, will be approximately $10 \%$ smaller. The agricultural production is intensive: both nitrogen and phosphorus surpluses on cultivated area are high in northern Finland as a result of all scenarios studied.

\section{Discussion and conclusions}

The aim of this study was to predict and compare the diversity effects of alternative agricultural policy reforms in Finland. When we evaluated the effects of policies on agricultural land use, the main finding was that the amount of fallow land, and especially that of green fallow, will increase considerably if agricultural support payments are decoupled from production. Although establishing a green fallow is more expensive than establishing a bare fallow, the maintenance costs of green fallows are lower than the respective costs of maintaining bare fallows. Based on the farm-level production cost calculations of the Union of Rural Advisory Centres (MKL 1995), this makes green fallows more profitable than bare fallows in a five-year period, and thus the predicted increase in the area of green fallows is justified. In addition, it should be noted that the above results depend on the environmental crosscompliance requirement of keeping the land in good agricultural condition included in the REF and LIB scenarios. Without this requirement, the decoupling of support payments may lead into land abandonment.

At landscape level, those policy reforms, in which support is decoupled, change land use and decrease diversity of agricultural land-cover classes in almost all parts of the country, except in northern Finland. The effect on the biological diversity, however, may not be as harmful as Shannon's diversity index implies, since at species level, green fallows seem to have some positive effects, especially on the densities and abundance of farmland birds, game animals and overwintering invertebrates (Haukioja et al. 1985, Helenius et al. 1995, Tiainen and Pakkala 2000, Tiainen and Pakkala 2001). Firbank et al. (2003) concluded that particularly rotational set-aside provides suitable habitats for breeding birds, but the benefits of short-term set-aside for rare arable plants in England were little. Corbet (1995), on the other hand, considered long-term set-aside as a possibility to establish patches of undisturbed perennial herbaceous vegetation and their associated fauna. Furthermore, Steffan-Dewenter and Tscharntke (1997), Critchley and Fowbert (2000) and Kuussaari and Heliölä (2004) remarked that green fallows are poorer habitats than meadows when considering species diversity of vascular plants or butterflies and other insects.

It is also interesting to note that if CAP support remained coupled to production, i.e. if the Agenda 2000 policy were to continue, there would be a risk that the area of land taken out of agricultural production might increase especially in southern and central Finland. This is be- 


\section{Miettinen, A. et al. On diversity effects of agricultural policy reforms}

cause it may be economically rational to leave land as it is, since agricultural support under Agenda 2000 is linked to production and the establishment of set-aside or fallow includes costs. Pykälä (2001) and Paukkunen and Raatikainen (2004) have assessed that the soil of fields is so enriched with nutrients that uncultivated fields will convert into forest fast if they are not regularly grazed or mown and plant biomass collected. In this case, the loss of visual landscape is evident, since, as a general rule, the scenic beauty of agricultural landscapes in Finland decreases with increasing intensity of afforestation (Tahvanainen et al. 1996, Hietala-Koivu et al. 1999, Tyrväinen and Tahvanainen 1999). Large-scale abandonment of agricultural land decreases also habitats of species living in agricultural environments, and they will be partly replaced by species thriven in woody habitats. The degree of decline in biodiversity in agricultural environments may also depend on initial land use (i.e. whether the abandoned areas are open fields or species-rich traditional rural biotopes). We compared agricultural land use at the aggregate level and found only minor changes between scenarios in the proportional distribution of the landcover classes that remain under cultivation or setaside. Most abandoned land will doubtlessly come from low-productive set-aside and grassland areas, but the increase in the marginal land area in the base scenario is so remarkable that also areas from other land-cover classes are left uncultivated. Studying this topic in more detail would require examining changes on field parcel level.

Of the single crops, it seems that the cultivated area of winter wheat will decrease from the current level as a result of each scenario studied. This is an unfavourable development from the points of view of biological diversity and potential nutrient leaching, since winter cereals offer vegetation cover for soil during winter. The area under another winter cereal, rye, is highly dependent on the crop price paid. In the calculations above, it was assumed that the 2002 price level for rye is retained only under Agenda 2000. The amount of cultivated grassland, on the oth- er hand, is closely linked to the effects of reforms in the dairy sector. The differences in grassland area and dairy cow numbers are moderate between the base and REF scenarios, but both scenarios differ significantly from the outcome of liberalised agricultural trade which results in smaller livestock units and grass area.

Everywhere except in northern Finland, the chemical pesticide application area is smaller under the REF and LIB scenarios than as a result of the base scenario, since cereal, potato and sugar beet areas will decrease if direct aid payments are decoupled from production. This will benefit, for example, farmland birds since reduced use of pesticides may increase the amount of insect prey.

In the aggregate level of Finland, the LIB scenario results in lower nitrogen and phosphorus surpluses than the base or REF scenarios in 2015. This is because livestock production, and especially the number of dairy cows, decreases if CAP animal support is fully decoupled. Although decrease in nutrient surpluses is desirable, a decline in livestock farming has also negative environmental effects since outdoor grazing tends to decline. Furthermore, the crop rotation on a farm becomes more simplified when the farmer exits animal husbandry, since grassland is no longer needed in the farm (Pitkänen 2001). It is also important to notice that decoupling direct aids from production will not necessarily lead into lower nutrient leaching potential from cultivated agricultural lands. This is because the cultivated area may relatively decrease even more than the number of livestock units, and this is exactly what happens under the on-going CAP reform scenario which in many areas leads into higher nutrient surpluses per cultivated area than the base scenario. In other words, although agricultural land use in future will be extensive at aggregate level, there may be some large production units and intensive geographical regions in Finland where animal production is concentrated. On one hand, this may cause environmental problems, but on the other hand, concentration of farming activities may facilitate the control of these problems. 
Vol. 13 (2004): 229-246.

Acknowledgements. The authors are indebted to Prof. Anni Huhtala for her constructive comments and cheerful encouragement. We also like to thank Ms. Anja Yli-Viikari for commenting on an earlier version of this paper. Furthermore, Reija Hietala-Koivu and Antti Miettinen especially acknowledge the contributions of Prof. Ilkka P. Laurila and the other members of the BIAPIA/Fibre research group in valuable discussions. We were privileged to belong to such a research group. Funding from the Academy of Finland and the Ministry of Agriculture and Forestry is gratefully acknowledged.

\section{Appendix}

\section{Main elements of the dynamic regional sector model of Finnish agriculture}

The dynamic regional sector model of Finnish agriculture (DREMFIA) is a dynamic recursive model which simulates the development of agricultural investments and markets from 1995 to 2020 . The structure of the model is presented in Figure A-1. The model consists of two major parts: (1) a technology diffusion model which determines sector level investments in different production technologies, and (2) an optimisation routine which simulates annual produc- tion decisions (within the limits of fixed factors) and price changes, i.e., supply and demand reactions, by maximising producer and consumer surpluses subject to regional product balance and resource (land and capital) constraints.

The most important medium- and long-term driving force of agricultural production in the model is the module of technology diffusion. Nevertheless, if major changes take place in production, price changes, as simulated by the optimisation model, are also important to consider. The Armington assumption, which means that imported and domestic products are imperfect substitutes, is utilised. The changes in domestic production and foreign trade of agricultural products imply price changes. Parameters of the demand system have been calibrated in order to replicate the expost price development in 1995-2002. Optimisation provides the annual market balance using the outcome of the previous year as the initial value. There are, however, restrictions on the annual changes of some production variables. The restrictions represent short-run technical and biological constraints in each production line. The restrictions are validated so that annual changes may be at least as large as the average annual changes in 1990-2002. Hence, the changes in land use may be relatively large (10-50\%) annually, and very large until 2015. The model reaches a steady-state equilibrium in a 10 to 15 year period when all variables, including capital, have reached an endogenous optimal solution.

The sector model includes four main regions, southern Finland, central Finland, Ostrobothnia, and northern Finland, and the production of these is further divided into sub-
Fig. A-1. Basic structure of the dynamic regional sector model of Finnish agriculture (DREMFIA).

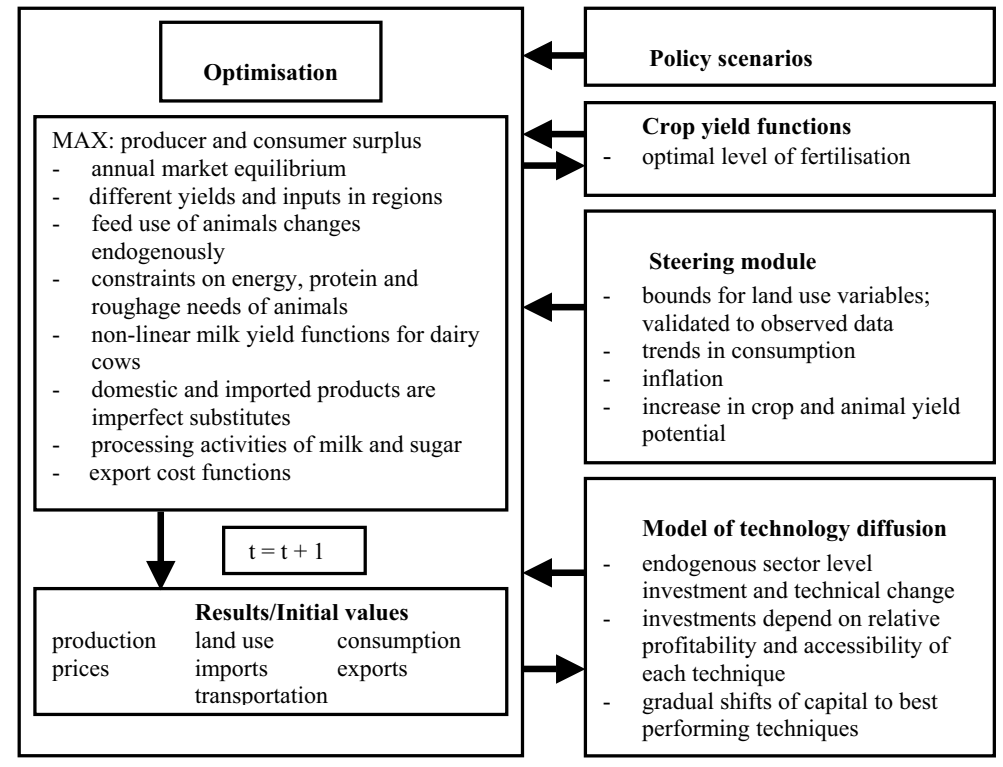




\section{Miettinen, A. et al. On diversity effects of agricultural policy reforms}

regions on the basis of agricultural support areas. The final and intermediate products can be transported between the main regions at certain transportation costs. Milk products and sugar are priced at the retail level. All other products are priced at the producer price level.

The optimal fertilisation level is determined by the fertilisation response function and by crop and fertiliser prices. Animal yields grow linearly in time, although feeding affects the milk yield of dairy cows. Certain energy, roughage and protein needs have to be fulfilled. No explicit connections to the other sectors of the economy are made. Inflation rate, price of labour, price elasticity of demand and exogenous trends for consumption represent general economic conditions and consumers' preferences.

The sector model caters for the most important production lines of agriculture, including crop production, dairy production, production of beef, pork and poultry meat, as well as egg production. The arable crops, as an example, comprise barley, oats, malting barley, mixed cereals, rye, wheat, oil-seed plants, sugar beets, potatoes for human consumption, starch potatoes, silage, green fodder, dry hay, and peas. Bare and green set-asides are also included in the model.

\section{References}

Ala-Mantila, O., Lehtonen, H., Aakkula, J., Knaapinen, P., Laurila, I.P. \& Niemi, J. 2000. Agenda 2000:n vaikutus Suomen maatalouteen. Maatalouden taloudellinen tutkimuslaitos. Tutkimuksia 244. Helsinki, Finland. $148 \mathrm{p}$.

Altieri, M.A. 1999. The ecological role of biodiversity in agroecosystems. Agriculture, Ecosystems and Environment 74: 19-31.

Collins, W.W. \& Hawtin, G.C. 1999. Conserving and using crop plant biodiversity in agroecosystems. In: Collins, W.W. \& Qualset, C.O. (eds.). Biodiversity in Agroecosystems. CRC Press. Boca Raton, FL, USA. p. 267-282.

Council of the European Union 2003. CAP reform - presidency compromise (in agreement with the commission). Cited 2 July 2004. Available on the Internet: http://register.consilium.eu.int/pdf/en/03/st10/ st10961en03.pdf.

Cooper, J., Johansson, R. \& Peters, M. 2003. Some domestic environmental effects of U.S. agricultural adjustments under liberalized trade. A preliminary analysis. Accepted Paper. In: International Conference "Agricultural policy reform and the WTO: where are we heading?" Capri, Italy; June 23-26, 2003. Cited 2 July 2004. Available on the Internet: http://www. ecostat.unical.it/2003agtradeconf/Contributed $\% 20$ papers/Cooper, $\% 20$ Johansson $\% 20$ and\%20Peters.pdf
Corbet, S.A. 1995. Insects, plants and succession: advantages of long-term set-aside. Agriculture, Ecosystems and Environment 53: 201-217.

Critchley, C.N.R. \& Fowbert, J.A. 2000. Development of vegetation on set-aside land for up to nine years from a national perspective. Agriculture, Ecosystems and Environment 79: 159-174.

Di Falco, S. \& Perrings, C. 2003. Crop genetic diversity, productivity and stability of agroecosystem. A theoretical and empirical investigation. Scottish Journal of Political Economy 50: 207-216.

Duelli, P. 1997. Biodiversity evaluation in agricultural landscapes: An approach at two different scales. Agriculture, Ecosystems and Environment 62: 81-91.

European Commission 2003a. Mid-term review of the Common Agricultural Policy. July proposals. Impact analyses. February 2003. European Commission, Directorate-General for Agriculture, Brussels. Cited 9 September 2003. Available on the Internet: http:// europa.eu.int/comm/agriculture/publi/reports/mtrimpact/rep_en.pdf

European Commission 2003b. Reform of the Common Agricultural Policy. A long-term perspective for sustainable agriculture. Impact Analysis. March 2003. European Commission, Directorate-General for Agriculture, Brussels. Cited 9 September 2003. Available on the Internet: http://europa.eu.int/comm/agriculture/publi/reports/reformimpact/rep_en.pdf

Firbank, L.G., Smart, S.M., Crabb, J., Critchley, C.N.R., Fowbert, J.W., Fuller, R.J., Gladders, P., Green, D.B., Henderson, I. \& Hill, M.O. 2003. Agronomic and ecological costs and benefits of set-aside in England. Agriculture, Ecosystem and Environment 95: 73-85.

Haukioja, M., Kalinainen, P. \& Nuotio, K. 1985. Maatalouden vaikutus peltolinnustoon: esitutkimusraportti. Ympäristöministeriön ympäristön- ja luonnonsuojeluosaston julkaisu A:34. Ympäristöministeriö. Helsinki, Finland. $50 \mathrm{p}$.

Helenius, J., Tuomola, S. \& Nummi, P. 1995. Viljely-ympäristön muutosten vaikutus peltopyyn ravintoon. Suomen Riista 41: 42-52.

Hietala-Koivu, R., Lankoski, J. \& Tarmi, S. 2004. Loss of biodiversity and its social cost in an agricultural landscape. Agriculture, Ecosystem and Environment 103: 75-83.

Hietala-Koivu, R., Tahvanainen, L., Nousiainen, I., Heikkilä, T., Alanen, A., Ihalainen, M., Tyrväinen, L. \& Helenius, J. 1999. Visuaalinen maisema maatalouden ympäristöohjelman vaikuttavuuden seurannassa. Maatalouden tutkimuskeskuksen julkaisuja. Sarja $A$ 50. Maatalouden tutkimuskeskus. Jokioinen, Finland. $27 \mathrm{p}$.

Jeanneret, Ph., Schüpbach, B. \& Luka, H. 2003. Quantifying the impact of landscape and habitat features on biodiversity in cultivated landscapes. Agriculture, Ecosystem and Environment 98: 311-320.

Kuussaari, M. \& Heliölä, J. 2004. Perhosten monimuotoisuus eteläsuomalaisilla maatalousalueilla. In: Kuussaari, M. et al. (eds.). Maatalouden ympäristötuen merkitys luonnon monimuotoisuudelle ja maisemalle: MYTVAS-seurantatutkimus 2000-2003. Suomen ympäristö (in press). 
Vol. 13 (2004): 229-246.

Lehtonen, H. 2001. Principles, structure and application of Dynamic Regional Sector Model of Finnish agriculture. Agrifood Research Finland, Economic Research (MTTL). Publications 98. Helsinki, Finland. 265 p.

Lehtonen, H. 2004. Impacts of de-coupling agricultural support on dairy investments and milk production volume in Finland. Acta Agriculturae Scandinavica, Section C-Economy 1, 1: 46-62.

McGarigal, K. \& Marks, B.J. 1995. FRAGSTATS: Spatial pattern analysis program for quantifying landscape structure. USDA Forest Services. PNW-GTR-351. Portland, OR, USA. 122 p.

MKL 1995. Mallilaskelmat. Suunnitteluosaston sarja A 24. Maaseutukeskusten liitto. Helsinki, Finland. 112 p.

MMM 2004. Implementation of the CAP-reform in Finland. Ministry of Agriculture and Forestry, Finland. Press release 26 May 2004. Cited 2 July 2004. Available on the Internet: http://www.mmm.fi/tiedotteet2/ tiedote. asp?nro=1481

MTT Agrifood Research Finland, Economic Research \& Pellervo Economic Research Institute 2004. The reform of the European Union's (EU) Common Agricultural Policy (CAP) in Finnish agriculture. In: Lehtonen, H. (ed.). CAP-uudistus Suomen maataloudessa. Helsinki, Finland. MTT:n selvityksiä 62. p. 13-21.

OECD 2001. Environmental indicators for agriculture. Methods and results. Volume 3. Organisation for Economic Co-operation and Development Paris, France. $409 \mathrm{p}$.

Olson, R.K. \& Francis, C.A. 1995. A hierarchical framework for evaluating diversity in agroecosystems. In: Olson, R. et al. (eds.). Exploring the role of diversity in sustainable agriculture. American Society of Agronomy. Madison, WI, USA. p. 5-34.

Paukkunen, J. \& Raatikainen, K. 2004. Tuoreiden niittyjen eliöyhteisöihin vaikuttavat paikalliset ja alueelliset tekijät. In: Kuussaari, M. et al. (eds.). Perinnebiotooppien kasvi- ja eläinlajiston säilyttäminen. Suomen ympäristö (in press).

Pitkänen, M. 2001. Plants. In: Pitkänen, M. \& Tiainen, J. (eds.). Biodiversity of agricultural landscapes in Finland. BirdLife Finland Conservation Series No. 3. Helsinki, Finland. p. 13-32.
Pykälä, J. 2001. Perinteinen karjatalous luonnon monimuotoisuuden ylläpitäjänä. Suomen ympäristö 495. Suomen ympäristökeskus. Helsinki, Finland. $205 \mathrm{p}$.

Shannon, C.E. 1948. A mathematical theory of communication. Bell System Technical Journal 27: 379-423, 623-656.

Southwood, R.E. \& Way, M.J. 1970. Ecological background to pest management. In: Rabb, R.C. \& Guthrie, F.E. (eds.). Concepts of pest management. North Carolina State University, Raleigh, NC, USA. p. 629.

Steffan-Dewender, I. \& Tscharntke, T. 1997. Early succession of butterfly and plant communities on setaside fields. Oecologia 109: 294-304.

Tahvanainen, L., Tyrväinen, L. \& Nousiainen, I. 1996. Effect of afforestation on the scenic value of rural landscape. Scandinavian Journal of Forest Research 11: 397-405.

Tiainen, J. \& Pakkala, T. 2000. Population changes and monitoring of farmland birds in Finland. In: Linnutvuosikirja 1999. BirdLife Suomi. Helsinki, Finland. p. 98-105.

Tiainen, J. \& Pakkala, T. 2001. Birds. In: Pitkänen, M. \& Tiainen, J. (eds.). Biodiversity of agricultural landscapes in Finland. BirdLife Finland Conservation Series No. 3. Helsinki, Finland. p. 33-50.

Topp, C.F.E. \& Mitchell, M. 2003. Forecasting the environmental and socio-economic consequences of changes in the Common Agricultural Policy. Agricultural Systems 76: 227-252.

Tyrväinen, L. \& Tahvanainen, L. 1999. Using computer graphics for assessing the aesthetic value of large scale landscapes. Scandinavian Journal of Forest Research 14: 282-288.

Uusitalo, P. 2003. Finnish farm. In: Niemi, J. \& Ahlstedt, J. (eds.). Finnish agriculture and rural industries. Agrifood Research Finland, Economic Research (MTTL). Publications 103a. Helsinki, Finland. p. 18-21.

Yearbook of Farm Statistics 2002. Official statistic of Finland. Agriculture, forestry and fishery 2002:65. Information Centre of the Ministry of Agriculture and Forestry. Helsinki, Finland. 266 p. 
Miettinen, A. et al. On diversity effects of agricultural policy reforms

\title{
SELOSTUS
}

\section{Maatalouspolitiilkkauudistusten vaikutuksista pellonkäytön diversiteettiin}

\author{
Antti Miettinen, Heikki Lehtonen ja Reija Hietala-Koivu \\ MTT (Maa- ja elintarviketalouden tutkimuskeskus) ja Helsingin yliopisto
}

Euroopan unioni uudistaa yhteistä maatalouspolitiikkaansa. Valtaosa EU:n kokonaan rahoittamista maataloustuista irrotetaan tuotannosta ja maksetaan viljelijöille tulotukena. Tutkimuksessa ennustettiin maatalouden sektorimallin avulla kuinka CAP-tukien irrottaminen tuotannosta vaikuttaa maatalousmaan käyttöön, tuotannon intensiteettiin sekä maiseman ja lajien monimuotoisuuteen Suomessa. Tarkasteltavia skenaarioita oli kaksi: yhteisen maatalouspolitiikan uudistusehdotusten mukainen skenaario ja vapaakauppaskenaario. Politiikkavaihtoehtojen tuloksena saatuja ennusteita maatalousmaan käytöstä, maiseman monimuotoisuudesta, torjunta-aineilla käsitellystä peltoalasta, eläintiheyksistä ja ravinnetaseista vuonna 2015 verrattiin perusskenaarion ennusteisiin vastaavana ajankohtana. Perusskenaariossa oletettiin, että myös tulevaisuudessa jatketaan Agenda 2000:n mukaista politiikkaa, jossa CAP-tuet on sidottu tuotantoon.

Yhteisen maatalouspolitiikan uudistusehdotusten mukainen CAP-tukien irrottaminen tuotannosta vä- hentää viljelymaiseman monimuotoisuutta useilla alueilla Suomessa ja johtaa lähes neljä kertaa suurempaan viherkesantojen pinta-alaan vuonna 2015 kuin Agenda 2000:n mukainen politiikka. Vapaakauppaskenaarion seurauksena pellonkäyttö muuttuu samansuuntaisesti, mutta voimakkaammin kuin CAP-uudistuksen perusteella. Maankäytön muutoksesta johtuvat vaikutukset maatalousluonnon monimuotoisuuteen eivät kuitenkaan todennäköisesti ole kokonaisuudessaan haitallisia, sillä viherkesantojen on todettu vaikuttavan myönteisesti etenkin peltolinnustoon. Sen sijaan kotieläintuotannon muutokset vaikuttavat todennäköisesti haitallisesti luonnon monimuotoisuuteen, sillä erityisesti nautakarjan määrä vähenee, mikäli viljelijän tuotantopäätös ei vaikuta tuen suuruuteen. Tällöin ravinneylijäämät pienenevät, mutta samalla karjasta luopuneiden tilojen viljelykierto yksipuolistuu, ja laiduntamisen hyödyt luonnon monimuotoisuudelle vähentyvät. 